\title{
STUDY OF THE CONSUMER PREFERENCE FOR MILK BRANDS IN COLOMBO DISTRICT
}

Paniyanduwage Thushari Asanka Jayasuriya 2006/2008

Thesis submitted to the University of Sri Jayawardenapura as partial fulfillment of the requirement for the award of the degree of Master of Food Science in Food Science and Technology. 
The work described in this thesis was carried out by me under the supervision of Professor Arthur Bamunuarachchi/Dr. L.N. Senaweera and a report on this has not been submitted in whole or in part to any University or any other Institution for another Degree/diploma.

\author{
Pon6uppy..... \\ P T A Jayasuriya \\ Index Number-MFS/204 \\ 2006/2008 \\ M.Sc. In Food Science and Technology, \\ Department of Food Science and Technology, \\ Faculty of Applied Sciences, \\ University of Sri Jayawardenapura \\ Gangodawila, Nugegoda, \\ Sri Lanka.
}


We certify that the above statement made by the candidate is true and this thesis is suitable for submission to the University for the purpose of evaluation.

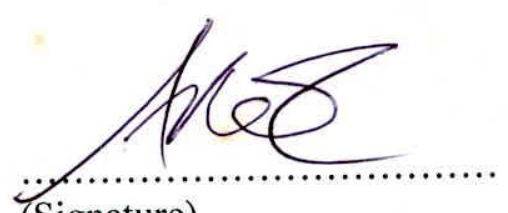

(Signature)

Prof. Arthur Bamunuarachchi

Professor of applied Chemistry,

Department of Food Science and Technology, Faculty of Applied sciences,

University of Sri Jayawardenapura

Gangodawila, Nugegoda,

Sri Lanka.

Tel/Fax: 94112828178

e-mail:arthurbamunu@yahoo.com

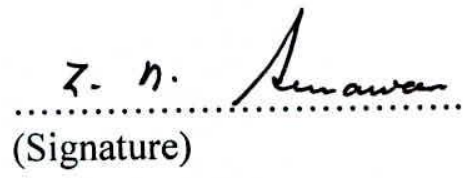

Dr. L.N. Senaweera

Director General

Sri Lanka Standards Institution

No.17, Victoria Place,

Elvitigala Mawatha,

Colombo-08,

Sri Lanka.

Tel/Fax: 94112671574

e-mail:dg@slsli.slt.lk 


\section{TABLE OF CONTENTS}

Table of contents $\quad$ i-ii

List of tables

List of figures

Acknowledgement $\quad \mathrm{v}$

Abstract vi

CHAPTER-01

$\begin{array}{lll}1.0 & \text { INTRODUCTION } & 01\end{array}$

CHAPTER-02

2.0 LITERATURE REVIEW 06

2.1 Composition of milk 08

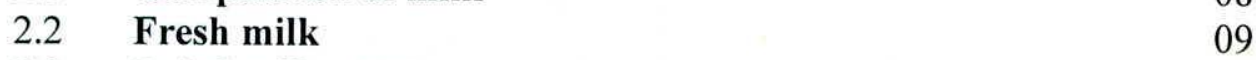

$\begin{array}{ll}2.3 \text { Dried milk powder } & 10\end{array}$

$\begin{array}{lll}2.4 & \text { Skimmed milk powder } & 10\end{array}$

$\begin{array}{lll}2.5 & \text { Sterilized milk } & 11\end{array}$

$\begin{array}{lll}2.6 & \text { Pasteurised milk } & 11\end{array}$

$\begin{array}{lll}2.7 & \text { Flavoured(pasteurised) milk } & 11\end{array}$

$\begin{array}{lll}2.8 & \text { Malted milk } & 12\end{array}$

2.9 Consumer and food interaction $\quad 12$

$\begin{array}{lll}2.10 & \text { Consumer preference studies } & 13\end{array}$

$\begin{array}{lll}2.11 & \text { Importance of sensory evaluation } & 14\end{array}$

2.12 Importance of sensory analysis 14

2.13 Sensory properties of food 15

2.14 Future trends in milk consumption 17

\section{CHAPTER-03}

3.0 EXPERIMENTAL 19

3.1 Study of the consumer preference for milk brands in Colombo 19 District

3.1.2. Method of statistical analysis 20

3.2 Sensory evaluation of tea with different milk brands 20

$\begin{array}{ll}3.2 .1 \text { Materials } & 20\end{array}$

$\begin{array}{ll}3.2 .2 \text { Method } & 20\end{array}$

$\begin{array}{ll}\text { 3.2.3 Method of statistical analysis } & 21\end{array}$

$\begin{array}{lll}3.3 & \text { Sensory evaluation of milk with different milk brands } & 21\end{array}$

$\begin{array}{ll}\text { 3.3.1.Materials } & 21\end{array}$

$\begin{array}{ll}\text { 3.3.2 Method } & 21\end{array}$

$\begin{array}{ll}\text { 3.3.3 Method of statistical analysis } & 22\end{array}$

$\begin{array}{lll}3.4 & \text { Solubility test } & 22\end{array}$

3.4.1. Materials 22

$\begin{array}{ll}3.4 .2 \text { Method } & 22\end{array}$ 


\section{CHAPTER-04}

4.1. Results of the consumer preference for milk brands

4.1.2.Friedman Test: Response versus Treatment blocked by Block

4.1.3. Friedman Test_-All pairwise comparisons

4.2 House hold income and the average monthly expenditure on milk

4.3 Proportion of milk consumed

4.4 Reasons for consuming milk brands

4.5 Time period of consumption of the specific milk brands 36

4.6 Results of sensory analysis of tea

4.7 Results of sensory analysis of milk

4.8 Results of Rank pre 39

4.8 Results of Rank preference test of tea 42

4.9 Results of Rank preference test of milk 44

4.10 Results of the solubility test of five brands of full cream milk powder

4.11 Comparison of nutrition status of different milk powder brands

CHAPTER-05

5.0 CONCLUSION

REFERENCES

APPENDICES 


\section{LIST OF TABLES}

1. Table- 01 Composition of milk of various mammals 08

2. Table-02 Results of the Friedman test for consumer preference 23

3. Table-03 Results of Friedman: all pairwise comparisons (Conover) 26

4. Table-04 Age group of the consumers responded for the questionnaire 28

5. Table-05 Sex of the consumers responded for the questionnaire 28

6. Table-06 Income level of the consumers responded for the questionnaire 29

7. Table-07 Average monthly expenditure for milk(Rs.)by a consumer 30 for a family

8. Table-08 Expenditure on milk as a percentage of the household income $\quad 30$

9. Table-09 Type of milk consumed as a percentage 31

10. Table-10 Reasons for consuming the milk/milk brands 35

11. Table-11 Time period of consumption of the specific milk brand 36

12. Table -12 Results of Kruskal- Wallis Test on taste of tea 37

13. Table -13 Results of Kruskal- Wallis Test on odour of tea 37

14. Table -14 Results of Kruskal- Wallis Test on mouthfeel of tea 38

15. Table -15 Results of Kruskal- Wallis Test on colour of tea 38

16. Table -16 Results of Kruskal- Wallis Test on taste of milk 39

17. Table -17 Results of Kruskal- Wallis Test on odour of milk 40

18. Table -18 Results of Kruskal- Wallis Test on mouthfeel of milk 40

19. Table -19 Results of Kruskal- Wallis Test on colour of milk 41

20. Table-20 Results of Rank preference test(with tea) between different brands of milk powders

21. Table-21 Results of Rank preference test(plain milk) between different brands of milk powders

22. Table -22 Comparison of nutrition information given in different brands of full cream milk powder

23. Table -23 Comparison of nutrition information given in skim milk powder 


\section{LIST OF FIGURES}

1. Figure-01- Main effects plot for median (for different milk brands) 24

2. Figure 02 -House hold income level Vs. percentage consumers 29

3. Figure 03 -Average monthly spending on milk(Rs.)by a consumer 30 


\section{Acknowledgement}

For their kind assistance, advice and guidance, I am indebted to Prof. Arthur

Bamunuarachchi, Professor of Applied Chemistry, Department of Food Science and Technology, University of Sri Jayawardenapura, and Dr. L.N. Senaweera, Director General, Sri Lanka Standards Institution.

I wish to thank Dr.K.K.D.S Ranaweera, the Head, Department of Food Science and Technology, University of Sri Jayawardenapura.

My thanks also due to the staff of the Quality Assurance Division who participated in the sensory evaluation procedure and the consumers who participated.

My special thanks for Iresha and Nilanga who helped me in conducting the sensory panel.

I appreciate the assistance provided by the Grama Niladaries of the selected divisional secretariate divisions.

Finally I thank my husband and my parents for the help and encouragement. 


\title{
STUDY OF THE CONSUMER PREFERENCE FOR MILK BRANDS IN COLOMBO DISTRICT
}

\author{
P T A Jayasuriya \\ Department of Food science and Technology \\ University of Sri Jayawardenapura
}

\begin{abstract}
Aim of this study was to find if there's significant difference for consumer preference in milk brands available in the market, to identify if consumers identify the difference in taste/odour/mouthfeel/colour in different brands and to find the proportion of consumers who prefer fresh milk/spray dried milk/sterilized/pasteurized milk.

The consumer preference study was carried out in random selected 6 divisional secretariat divisions in Colombo district. Data was obtained by interviewing consumers using the preprepared questionnaire. Sensory evaluation of tea and milk was carried out using a sensory evaluation form which included a rank preference.

This study revealed that there is a significant difference for preference in milk brands available in the market in which Anchor brand has the highest preference and $83 \%$ consumers preferred spray dried milk powder. Fresh milk consumption is $2 \%$, and total of $11 \%$ consume fresh milk, spray dried milk powder in combination. Pasteurized milk consumption is $3 \%$, but they consume full cream milk powder along with pasteurized and pasteurized flavoured milk. In sensory analysis it was found that only the taste of tea had a significant difference and odour, mouthfeel and colour did not have a significant difference identified in tea and milk.
\end{abstract}




\section{CHAPTER-1}

\subsection{INTRODUCTION}

Milk as an article of food, dates back to the earliest recorded times. The importance of milk in the human dietary cannot be overstressed.

Milk is considered as the most valuable and nutritious product for the human consumption. It is the most suitable and elaborate substance provided by nature. Milk cannot be preserved in its fresh condition for long time and soon it is fermented or destroyed by the life activities of the different types of microorganisms that gain entrance to milk from various sources.

Practically everyone consumes some milk or milk derivative, knowingly or unknowingly. The first prerequisite of a food is that it must be palatable. It must be relished and enjoyed when consumed. Milk and milk products are liked by most people. There are great deal of variations which can be managed to make milk products acceptable by those who do not care for it in its natural state. Though it is essential that major constituents be present in a food, yet it $\mathrm{s}$ more crucial that most of these constituents be readily available for utilization by human body. The percentage of various food constituents of milk which are digested is very high. It is possible for certain individuals to utilize as much as 98 percent of proteins and 99 percent of carbohydrates and fat.

If a food is inherently clean, it is bound to increase the appeals of the average consumer. The milk and milk products being clean, wholesome and nutritious attract the attention of masses and create a desire for such food. Milk for direct consumption can be prepared under very sanitary conditions maintaining the highest quality. In contrast to other foods, milk contains constituents of all classes needed by the body.

Thus an interest of this important food is justified. 
Milk may be defined as the normal secretion of the mammary glands of most mammals. The nature designed milk as a food for the newly born and the growing young's. The perfect composition of milk not only recommends itself for the growing organism, but is also suited to satisfy the energy and vitamin requirements of the adult system.

It is a heterogeneous product in which fat, proteins, sugar, vitamins and mineral salts are held in emulsion, colloidal suspension or solution $\mathrm{n}$ the major constituent, i.e. water.

In spite of its nutritional value, milk is mostly water $(87 \%-87.5 \%)$. Its nutrients are as follows;

1. The protein content averages about $3.2 \%$. Of this $80 \%$ is casein; the balance is present in the whey-the portion remaining after the casein is removed. The white colour of milk is due primarily to the calcium caseinate. Milk proteins are ideal in that they are complete proteins and high in the essential amino acids.

2. Butter fat content averages about $3.8 \%$ but varies considerably with the breed of cattle.

3. Milk contains about $4 \%$ carbohydrates made up primarily of lactose or milk sugar. Lactose is remarkable in that it only known to occur in milk. It is a disaccharide made up of a molecule of glucose and a molecule of galactose.

Variety of milk and milk products are produced in the dairy depending on consumer requirements. These include the following categories of products which are consumed in Sri Lanka.

Fresh milk- Raw milk, pasteurized and sterilized, spray dried full cream milk, skim milk (non fat)."Milk raw or fresh" means the normal, clear, lacteal secretion obtained by complete milking, of one or more healthy cows or buffaloes without the addition of any substances or extraction of fats or any other constituents. 
"Toned milk" means a product prepared by the abstraction of suitable quantity of milk fat from cow milk or buffalo milk or combination of both.

"Skimmed milk" means, a product prepared from cow milk, buffalo milk or combination of both, from which almost all the milk fat has been removed and containing not more than 0.5 percent fat.

"Pasteurized milk" means, milk that has been heated in such a way that every particle of milk is heated to at least $63^{\circ} \mathrm{C}$, and held continuously at that temperature for at least 30 minutes, or heated to at least $71.5^{\circ} \mathrm{C}$, and held at that temperature continuously for at least 15 seconds, or any other approved temperature-time combination.

"Sterilized milk" means, milk that has been heated without appreciable loss of volume, to a temperature of $100^{\circ} \mathrm{C}$ for a length of time sufficient to kill all the organisms present, and contained for delivery in hermetically sealed containers.

There are different milk brands available in the local market.

The most basic outcome of a marketing strategy is an image of the product or brand in the consumer's mind. This image consists of a set of beliefs, pictorial representations, and feelings about the product or brand. It is determined by communications about the brand as well as by direct experience with it.

In Sri Lanka per capita availability of cow milk is $4.01 \mathrm{~kg} /$ year and Buffalo milk $1.33 \mathrm{~kg} /$ year (Statistical Abstract-2005, dept. Census and Statistics). Whole dried milk per capita is $1.42 \mathrm{~kg} /$ year.

Per capita availability of whole dried milk(tinned)3.46kg/year and per capita availability of condensed milk 0.27kg/year (Statistical Abstract-2005, dept. Census and Statistics). The gross imports of Whole dried milk(tinned) are 54.02(000 MT)

In Sri Lanka total import value for milk and milk products is (in Rs. Million)17,760 for year 2006.(Central Bank Annual report). This is $1.7 \%$ of total imports. 
But local production of spray dried milk powder is insufficient for the demand. The National milk production(million liters) for cow milk-165 mn liters and Buffalo milk 32 mn liters.

Only two spray drying factories, namely Highland and Nestle continues the production of spray drying milk powder in Sri Lanka. So there's a high demand for imported spray dried milk powder. The major brands of imported milk powder are Anchor, Nestle, Red cow, Anelene, Maliban, Lakspray, Raththi, Milgro. The major fresh milk (sterilized) brands are Highland(fat free and full cream), Richlife(non fat and low fat), Ambewela(fresh milk) Nestle, and Kotmale. There's a high competition among these brands and even with high escalating prices consumers still tends to buy milk brands. So this study of consumer preference is aimed in order to find if there's a significant difference among these milk brands. 
Objectives of this study are;

1. To find if there's significant difference for consumer preference in milk brands available in the market.

2. To find if the consumers identify a difference in taste/odour/mouthfeel/colour in different brands.

3. To find the proportion of consumers who prefer fresh milk/spray dried milk/sterilized/pasteurized milk. 


\subsection{LITERATURE REVIEW}

\section{CHAPTER-02}

Throughout his life span man retains a need for a large number of chemicals, known as nutrients. The number and variety of his chemical needs does not change with age but the proportionate amounts of each depend on many factors of which sex and the rate of growth or accretion of new tissue is perhaps the most important if one excludes the calories needed to support the basic life processes of the body and physical work done.(Ohlson,1958))

Milk is as ancient as mankind itself, as it is the substance created to feed the mammalian infant. All species of mammals, from man to whales, produce milk for this purpose. Many centuries ago, perhaps as early as $6000-8000 \mathrm{BC}$, ancient man learned to domesticate species of animals for the provision of milk to be consumed by them. These included cows (genus Bos), Buffaloes, sheep, goats and camels, all of which are still used in various parts of the world for the production of milk for human consumption.(Parihar,2006)

The role of milk in the traditional diet has varied greatly in different regions of the world. The tropical countries have not been traditional milk consumers, whereas the more northern regions of the world, Europe and North America, have traditionally consumed far more milk and milk products in their diet. In tropical countries where high temperature and lack of refrigeration has led to the inability to produce and store fresh milk, milk has traditionally been preserved through means other than refrigeration, including immediate consumption of warm milk after milking, by boiling milk, or by conversion in to more stable products.(Parihar,2006)

Milk is considered as the most valuable and nutritious product for the human consumption. 